\title{
The Correlation between Transformational Leadership Styles with Teacher's Performance in SMP Negeri 2 Medan
}

\author{
Hendri Fauza \\ Lecturer at Tarbiyah Faculty, Universitas Islam Negeri Sumatera Utara, Indonesia \\ hendrifauza@uinsu.ac.id
}

\begin{abstract}
This study aims to determine the principal's transformational leadership style used by SMP Negeri 2 Medan and the Performance of Teachers. The population in this study were all teachers in SMP Negeri 2 Medan. As a sample taken the entire study population using total sampling techniques. From the results of the study note that there is a positive relationship between the principal's transformational leadership style with the performance of teachers in SMP Negeri 2 Medan in the amount of rxy $=0.471>0.266$. So from the hypothesis test results above it can be said that there is a relationship between Work Motivation and Teacher Job Satisfaction in An-Nizam Islamic Elementary School, where $r_{\text {observe }}>r_{\text {table }}(0.471>0.266)$ hypothesis is accepted with the meaning $\mathrm{Ha}$ is accepted and Ho is rejected if $r$ observe $<r_{\text {table. }}$ This level of relationship is included in the Medium level relationship interval.
\end{abstract}

\section{Keywords}

principal transformational; leadership style; teacher performance

\section{Introduction}

Transformational leadership is a central approach to leadership and has a key position in the new theory related to leadership as a process, regardless of the activity. Leaders to be successful and functional, timely need to start understanding and acceptance of change and to develop the potential they have, which will contribute to the success of the organization. It is thought that transformational leadership only lead to fundamental changes in the organization. Individuals who have made significant contributions to their organizations and their personal vision and energy to inspire followers are called charismatic or transformational leaders (Ackoff, 1999).

Furthermore Saragih (2019) states teacher performance is the implementation of a plan that has been prepared through planning good learning activities that is by completing learning tools in the form of syllabus and learning implementation plans (RPP) instead planning poor learning activities if the teacher does not prepare learning tools in the form of syllabus and lesson plans. Implementation of performance is carried out by human resources who have the ability, competence, motivation, and interests. How madrasas respect and treat their human resources will influence their attitudes and behavior in carrying out performance.(Saragih,2019)

The life of an organization is largely determined by the role of a leader. The existence of a leader plays an important role in running the wheels of the organization, in accordance with its role as a direction and direction of the future, change agents, negotiators, and coaches. Although the role of a leader is crucial, the leader cannot work alone without the support of his subordinates. This means the leader must relate to his subordinates to influence their feelings, thoughts, and attitudes so that his leadership is accepted by his subordinates (Marno, Triyo Supriyatno. 2016:49). 
Griffin R. (2007) says that leadership is very important for the development of every human activity and in general for the whole social environment. As a phenomenon, leadership is a key for success of companies, so it plays great attention both in theory and in practice. Leaders who are able to encourage, change and use values, beliefs and needs of their followers' execution of tasks in crisis situations and dynamic major changes are transformational leaders.

Among the many leadership styles that exist today, the most interesting to talk about is the transformational leadership style. This leadership style is believed to be able to balance the mindset in the current globalization. Transformational leadership is described as leadership that awakens and motivates employees to be able to develop and reach a higher level so that they are able to achieve more than they expected before.

Transformational leadership is focused on the relationship between leaders and followers. It is characteristic that drivers who use transformational leadership have strong self-awareness and use a variety of soft skills that get other people. Leaders are well-built, conscientious and intelligent, and are able to followers to present a new vision that will inspire enthusiasm, creative energy and full commitment to achieve the vision set (Micevski, T., 2009).

Based on findings in the field, researchers believe there are several factors that determine the quality of the performance of teachers in SMP Negeri 2 Medan. The first factor that is believed to be a relationship to the quality of performance of teachers is the leadership of the headmaster madrasah with the school principal's transformational leadership point of view.

In this case, it is necessary to have leaders who have leadership behaviours that are able to inspire and motivate teachers to achieve results or goals greater than planned through the transformational leadership style. This type of leader who gives consideration and intellectual stimulation that is individualized, and who has charisma. Transformational leaders pay attention to the concerns and development needs of individual followers, they change followers' awareness of problems by helping them see problems in new ways, and they can inspire followers to achieve their desired goals.

A transformational process occurs in leadership relationships when the leader builds subordinates' awareness of the importance of work values, expands and increases needs beyond personal interests, and drives these changes towards shared interests including organizational interests.

Transformational leaders must be able to invite subordinates to make changes where these changes affect the performance of the employees themselves. Communication must always be done by the leader to his subordinates in achieving the mission that will be carried out.

Furthermore, to strengthen this pre-study, researcher often communicated with Syufri Effendi, as the administrative staff at SMP Negeri 2 Medan, saying there had been a change in teacher performance since the headmaster had a transformational leadership style.

Suyatminah in BK's Journal (2013: 91) explains the results of her research that transformational leadership is a factor that greatly influences performance. If the factor is owned by the principal, it can improve teacher performance.

This phenomenon shows that the teacher's performance in general is included in the increased category. This is because of the appearance of the principal who has a transformational leadership style that has a high managerial ability in leading and nurturing his teachers to improve the performance of his teacher. Various efforts are undertaken and 
implemented by the principal to improve the performance of his teacher, including holding weekly, monthly, semester, and annual meetings to communicate everything in improving the performance of his teachers. Also presenting their teachers in the MGMP (Subject Teachers' Deliberation) and proposing education and training (Diklat), giving rewards and punishment, a kind of reward and punishment to every teacher who excels and violates the rules or contract agreements that have been promised and communicated. The punishments punishments that were given did not reach expenditures for teachers who were categorized as violating the fatal school regulations.

Not all teachers obey the rules and policies of the principal. However, only a small portion of those who make mistakes or violate the rules of this school. The rest is more teachers who really show discipline and good quality performance. However, there are still teachers who have not been maximal in carrying out their duties and responsibilities as a teacher, however, the headmaster continues to work together with his teacher to always improve his performance and responsibilities as a teacher to achieve the desired goals.

From this picture of the performance of teachers at SMP Negeri 2 Medan, this is the basis for research into a change from transformational headmaster leadership with improved teacher performance.

Based on the results of previous research studies that there is a reality in the field at SMP Negeri 2 Medan which is the focus and object of this research, that the factor of the transformational leadership style of the school principal is considered to have an effect on teacher performance. Because of the 37-teacher data, more than half of the teachers performed well. However, there are still teachers who are still underperforming, even though the school principal has given a warning and sanctions to the teacher in the form of reduced teaching hours.

Departing from factors or variables that affect teacher performance, namely the principal's transformational leadership style that will be taken and made as Independent Variables (independent variable as $\mathrm{X} 1$ ) to be associated with Dependent Variables (Dependent variable as Y). So, researchers are interested in researching this in quantitative research methodologies.

For this reason, scientific research is needed to explain the transformational leadership style. What has been going on so far, and what has not worked in the teacher performance improvement program through the effectiveness of transformational leadership in the future.

\section{Review of Literature}

\subsection{Teacher Performance}

Performance in English is called performance, which can be interpreted by: (1) work; deed or (2) appearance. Performance has a broader meaning, not just expressing it as a result of work, but how the work process takes place. Performance is about doing work and the results achieved from the job. Performance is about what is done and how to do it. Performance is the result of work that has a strong relationship with the organization's strategic goals, customer satisfaction and economic contribution (Wibowo, 2007: 5).

Meanwhile performance according to Yuniarsih and Suwatno (2008: 161) is a real achievement that is displayed by someone after the person in charge of carrying out their duties and roles in the organization. This is similar to what was stated by Wibowo (2007: 7) that performance is the result of work that has a strong relationship with the organization's strategic goals, customer satisfaction and economic contribution. 


\subsection{Empowerment of Teacher's}

Meeting Empowerment is a translation of the word "empowering" which means developing human and other material resources. Empowering means encouraging becoming more involved in decisions and activities that affect individual work. Robbin as quoted by Wibowo (2007: 112) describes empowerment as placing individuals accountable for what they do. The same thing was expressed by Greenberg and Baron in Wibowo (2007: 112) explaining that empowerment is a process in which individuals are given an increase in a number of autonomy and flexibility in relation to their work. Tjiptono and Diana (2000: 128) define empowerment as involving individuals who really mean (significant).

Meanwhile Newstrom and Davis in Wibowo (2007: 113) explain that empowerment is every process that gives greater autonomy to individuals through exchanging relevant information and provisions on supervision over factors that influence work performance. Based on the explanation above, it can be interpreted that empowerment is a process to become individuals who are more empowered or more capable of completing their work by providing trust and authority so as to foster a sense of responsibility.

\subsection{Achievement Motivation}

Motivation in English called "motivation" comes from the Latin word "movere" which means to move (move or push). Lunenberg and Ornstein, as cited by Kamars (2005: 148), suggest that "motivation has been as" those processes within an individual that stimulate behavior and channel it in ways that should benefit the organization as a whole ". This means that motivation is a process in a person to stimulate behavior and channel it in ways that provide benefits to the organization as a whole. The notion that was introduced by Lunenberg and Ornstein is an understanding that leads to motivation that is in a person when in an organization, as an employee/ labor. In line with that Usman (2008: 245), revealed that motivation is the desire to do something, while the motive is the need (need), desire (wish), encouragement (desire) or impulse. So motivation is a desire found in someone to take actions or something that is the basis or reason for someone behaving. When connected with work, work motivation is nothing but the desires or needs that lie behind a person so that he is motivated to work.

Achievement according to Luthans (2006: 274) is the rate at which people hope to complete challenging goals, succeed in competition, and show a desire for clear feedback related to performance. From this definition, achievement motivation is nothing but the desire of someone to complete a job that is challenging and successful in every competition faced. This is in line with what was stated by Usman (2008: 259) that achievement motivation is an internal drive to overcome all obstacles and challenges in an effort to achieve goals.

\section{Research Method}

This research was conducted at SMP Negeri 2 Medan on Jalan Pemuda No.125. The reason for taking this location is because the school is considered to be a school that has a good and superior quality education and has outstanding student students, while this research will be conducted in April-May 2018. The population is the whole object to be or want to be examined. The population in this study was all teachers who were in SMP Negeri 2 Medan, amounting to 37 people. The sample is a part of the number and characteristics possessed by the population (Syahrum dan Salim: 2014). The total sample is the entire population concurrently as a research sample (Indra Jaya: 2013; Burhan Bungin: 2010). Based on these provisions, thus the sample of this study is total sampling, because the total population is less than 100 people, as many as 37 people so that all samples are used. In this case, the number 
of samples is 37 people namely population research, because the subject is less than 100 people and at the same time be respondents in this study. To obtain data and information in this study, the authors use data collection techniques by using questionnaire. The data analysis technique is using correlation and regression.

\section{Discussion}

The Relationship of the Principal Transformational Leadership Style (X) and Teacher Performance (Y).

Based on the description of research data, it can be seen that the principal's transformational leadership style on teacher performance in SMP Negeri 2 Medan in terms of frequency with 37 respondents. So, it can be said that most of the teachers of SMP Negeri 2 Medan think that it is high, starting from planning, implementation to evaluation. The principal has performed his function well as a leader who has a transformational style.

From the results of the study it can be concluded that there is a positive influence on the principal's transformational leadership style with teacher performance. This can be shown by the t-value of 4.275 with a significance value of 0.046 and a coefficient value of 52.114. Because the regression coefficient has a positive value and a significance value $(p)<0.05$, it can be concluded, the higher the transformational leadership style of the principal, the higher the teacher's performance will be. This also applies to the opposite, namely if the principal's transformational leadership style is low, the teacher's performance will also be lower.

Transformational change can only exist if it is firmly embedded in organizational culture. New values shared and forms of behavior and attitudes need to be highlighted to improve performance. In addition, it is necessary to invest sufficient time to ensure that the next generation of managers will be the personification of the new approach. Through the process mentioned above 8 stages can be suppressed destructively, and ensure the success of transformative efforts.

\section{Conclusion}

Based on the results of the hypothesis test described in chapter IV, this research can be concluded as follows:

1. The principal's leadership style in SMP Negeri 2 Medan can be said to be good because it is seen from the analysis test that has been done.

2. Teacher performance in SMP Negeri 2 Medan can also be said to be good because seen from the requirements test and analysis test that has been done.

3. Between the principals' transformational leadership style variables $(X)$ and the teacher performance variable $(\mathrm{Y})$ there is a significant relationship. This can be shown by the $\mathrm{t}$-value of 4.275 with a significance value of 0.046 and a coefficient value of 52.114.

\section{References}

Ackoff, R. L. (1999). Transformational leadership. In Strategy \& Leadership. https://doi.org/10.1108/eb054626.

Aan komariah,Engkoswara. (2015). Administrasi Pendidikan. Bandung: Alfabeta.

Siahaan, Amiruddin. (2012). Manajemen Perubahan. Jakarta: Andi Offset.

Arikunto, Suharsimi. (2013). Prosedur Penelitian Suatu Pendekatan Praktik. Jakarta.: Rineka Cipta. 
Cahya putra rustamaji, Army. Gaya kepemimpinan kepala sekolah dan kinerja guru SMK Swastadi Jakarta Timur. Jurnal psikopedagogia. Vol 5. no. 2 oktober 2017.

Danim, Sudarwan. (2005). Menjadi Komunitas Pembelajar Kepemimpinan Transformasional Dalam komunitas organisasi pembelajar.Jakarta: Bumi Aksara

Dubrin. Andrew J. (2006). The Complete Ideal's Guides Leadership, Jakarta: Prenada Media Griffin, R. (2010). Fundamentals of management. Library "Iskra", Genex.

Helmawati. (2014). Meningkatkan kinerja kepala sekolah/ adrasah melalui Manajerial Skill, Jakarta: Rineka Cipta

Hisbanarto. Yakub Vico. (2014). Sistem Informasi Manajemen Pendidikan. Yogyakarta: Graha Ilmu

Jaya, Indra. (2013). Penerpan Statistik Untuk Pendidikan. Bandung : Cita Pustaka Media Perintis

Juni Priansa, Donni. (2014). Kinerja dan Profesionalisme Guru. Bandung: Alfabeta.

Micevski, T. (2009). Management, University "Goce Delchev" - Stip, Faculty of Economics.

Mesiono. (2015). Manajemen Dan organisasi. Medan: Citapustaka Media Perintis

Mulyasa. (2013). Manajemen dan kepemimpinan kepala sekolah. Jakarta: Bumi Aksara

Nasution, Irwan. (2013). Administrasi Pendidikan, Medan: Perdana Publishing.

Raihani. (2010). Kepemimpinan sekolah Transformatif Yogyakarta: Lkis Printis Cemerlang

Rivai, et al. Veithzal. (2014). Pemimpin dan Kepemimpinan dalam Organisasi, Jakarta: Rajagrafindo Persada

Saragih, S. L., et al. (2019). The Relation between the Empowerment of Teacher's Meeting and Achievement Motivation on Teacher Performances in MTsN 3 (Islamic Junior High School 3) Simalungun. Budapest International Research and Critics in Linguistics and Education (BirLE) Journal. p. 115-114.

Siahaan, et al. A miruddin. (2013). Administrasi satuan pendidikan pendekatan sistemik dalam pengelolaan pendidikan untuk meningkatkan efektivitas pencapaian tujuan pada satuan pendidikan. Medan: Perdana Publishing

S. Ruky, Achmad. (2006). SDM Berkualitas Mengubah Visi Menjadi Realitas. Jakarta: PT. Gramedia Pustaka Utama

Sugiyono. (2015). Metode Penelitian Pendidikan Pendekatan Kuantitatif, Kualitatif, dan R\&D. Bandung : Alfabeta

Supardi. (2015). Kinerja Guru. Jakarta: PT Raja Grafindo Persada

Susmiyati. (2016). Pengaruh Kepemimpinan Transformasional dan Kompetensi Manajerial Kepala Sekolah terhadap Kinerja Guru di Madrasah Aliyah Negeri Se-Kabupaten Tulungagung. Jurnal Episteme. Vol.11, No.1.

Suyatmiyah. (2013) Peran Kepemimpinan Trasnformasional Dan Kedisiplinan Kerja Terhadap Kinerja Guru Tk Pns Se- Kecamatan Bantul. Jurnal psikopedagogia. Vol 2.no. 2.

Syafaruddin. (2008). Efektivitas Kebijakan Pendidikan ( konsep, strategi, dan aplikasi kebijakan menuju organisasi sekolah efektif). Jakarta: Rineka cipta.

Syafaruddin. (2008). Manajemen Mutu terpadu Dalam Pendidikan. Jakarta: Grasindo.

Syahrum and Salim. (2008) Metodologi Penelitian Kuantutatif. Bandung Citapustaka Media.

Tisnawati, Erni and Kurniawan saefullah. (2008). Pengantar Manajemen. Jakarta: Kencana.

Tjiptono, F. and Diana, A. (2004). Total Quality Management. Yogyakarta: Andi Offset

Wahyosumidjo. (2008). Kepemimpinan Kepala Sekolah. Jakarta: Rajagrafindo Persada.

Wibowo. (2007). Manajemen Kinerja, Jakarta: PT Raja Grafindo Persada.

Yuniarsih, T. dan Suwatno. ( 2008). Manajemen Sumber Daya Manusia. Teori, Aplikasi dan Isu Penelitian. Bandung: Alfabeta. 